\title{
An updated annotated checklist of scale insects (Hemiptera, Sternorrhyncha, Coccomorpha) of Poland
}

\author{
Bożena Łagowska', Katarzyna Golan' \\ I Department of Plant Protection, University of Life Sciences in Lublin, Leszczyńskiego 7, 20-069 Lublin, Poland \\ Corresponding author: Katarzyna Golan (katarzyna.golan@up.lublin.pl)
}

Academic editor: Roger Blackman | Received 9 December 2019 | Accepted 17 February 2020 | Published 12 March 2020

http://zoobank.org/75237497-FDA1-49E4-883C-2FDB1436041F

Citation: Łagowska B, Golan K (2020) An updated annotated checklist of scale insects (Hemiptera, Sternorrhyncha, Coccomorpha) of Poland. ZooKeys 918: 65-81. https://doi.org/10.3897/zookeys.918.49126

\begin{abstract}
A checklist of scale insects recorded to date in Poland is presented. The data provided here are based on literature records and include the latest taxonomic and nomenclatural changes and updates on Coccomorpha reported in Poland. Changes in comparison with ScaleNet and Fauna Europaea electronic databases are also discussed. A total of 185 species belonging to 98 genera and 16 families are included in the list. Of this group, 47 species are alien introduced species and live only indoors, and one species, Pulvinaria floccifera (Westwood), develops both indoors and outdoors.
\end{abstract}

\section{Keywords}

Coccoids, native and alien species, validation source

\section{Introduction}

Scale insects form a relatively small group of insects in the Polish fauna and represent only approximately $0.7 \%$ of the 27,000 insect species currently known in Poland. However, a few species are identified as pests of economic importance, and especially, in recent years, the invasion of alien scale insects has been observed in several parts of Poland (Łagowska et al. 2015, 2018; Golan et al. 2017).

Scale insects have been known for centuries in Poland for the carmine dye extracted from the Polish cochineal scale Porphyrophora polonica (Linnaeus). The presence of $P$. polonica in Poland was reported for the first time in the $16^{\text {th }}$ century (Miechowita 1521) and 
information about the harmful scale insects was published in later years by some authors (Trzebiński 1916; Ruszkowski 1925, 1933; Minkiewicz 1926). Advanced studies on the scale insect fauna of Poland were initiated by Kawecki, whose results have been presented in numerous publications from 1935 to 1985 . In the same period and later, Koteja and Koteja and Żak-Ogaza, in publications from 1964 to 2000, extensively studied the Coccomorpha and greatly contributed to the knowledge of the scale insect fauna in Poland. Further contributions are due to the studies by Komosińska (1961-1987), Komosińska and Podsiadło (1967), Dziedzicka (1970-1990), Podsiadło (1975); Podsiadło and Komosińska (1976), Łagowska (1990-2005), Łagowska and Koteja (1996), Dziedzicka and Karnkowski (1999), Łagowska and Golan (2005) and Łagowska et al. (2015, 2017, 2018).

Finally, 90 native and greenhouse species of scale insects that were new to the Polish fauna were discovered in the years 1961-1980 (Koteja 1985; Łagowska and Golan 2005). However, the records of species new to the Polish fauna significantly decreased from 32 in the period 1971-1980 to 8 in 1991-2005 (Łagowska and Golan 2005), and only another 8 new species were recorded in Poland in 2006-2019.

The early data on the distribution of scale insects in Poland were summarized by Kawecki (1985) in a catalogue listing 170 species, including 34 indoor species, and 11 records of misidentified species or species for which no host plants or localities were given. Later, two checklists of scale insects in Poland were presented by Koteja (1996) and Łagowska (2004) who reported 184 and 185 species respectively, each including 44 indoor species. In addition, an annotated list of alien scale insects present in Poland was published by Łagowska et al. (2015).

Two electronic databases provide important world-wide information on scale insect distribution: the Fauna Europaea ( FaEu) database (Burckhardt 2013), which reports 163 species of scale insects from Poland, and the ScaleNet database (García Morales et al. 2016), which lists 177 species. Since the last checklist (Łagowska 2004), several new records of scale insects from Poland have been published (Łabanowski 2009; Kalandyk and Węgierek 2010; Kozár et al. 2013; Łagowska et al. 2015, 2018). In the meantime, the nomenclature of the scale insects has also been partially changed. Moreover, several records reported in FaEu and ScaleNet databases were regarded as doubtful or erroneous and need revision. The present paper provides a comprehensive revised list of the scale insects of Poland with updated nomenclature and references to the first reliable Polish records of each species. In addition, discrepancies between the present list and the last checklist (Łagowska 2004) as well as differences from the records reported in the FaEu and ScaleNet databases are discussed.

The aim of the present checklist is to provide baseline reliable data for future faunistic and taxonomic studies.

\section{Materials and methods}

The list presented in this paper is based on the literature records of Coccomorpha in Poland available up to September 2019. A reference to the first reliable record of each species is included. Fossil species of scale insects and those that have been 
intercepted only once on imported plant materials are excluded. Families and species within each family are listed in alphabetical order according to the classification used in the ScaleNet database (García Morales et al. 2016). The references to species recorded in Poland reported in FaEu and ScaleNet have been checked and, if erroneous, corrected in the present lists. Changes in systematic status and synonymies, mostly proposed by Kozár et al. (2013) and Danzig and Gavrilov-Zimin (2014, 2015), and presently accepted in ScaleNet database, have been adopted in the present list. Scale insect species recorded in Poland are listed in Table 1 . They belong to four categories as follows: (i) native species; (ii) alien species established outdoors; (iii) alien species established indoors; and (iv) alien species that can live and develop both outdoors and indoors. The definition of alien species in this paper is the one proposed by Łagowska et al. (2015).

\section{Results}

At the present time the Polish scale insect fauna comprises a total of 185 species, distributed in 98 genera and 16 families. The Pseudococcidae are the most numerous family, with 50 recorded species, followed by Diaspididae (48 species), Coccidae (43 species), and Eriococcidae (sensu lato) (18 species) (Table 1). The remaining 12 families are each represented by $1-5$ species. The ratio of species to genera differs between families. The highest ratio (2.6:1) is in the Eriococcidae, followed by Coccidae (2.3:1), Diaspididae (2.0:1), and Kermesidae (2.0:1) (Table 2). The ratio of species number per genus in the Pseudococcidae family is $1.8: 1$, which is close to the general mean ratio of 1.9:1 reported for Poland (Table 2).

Table I. Checklist of scale insects (Hemiptera: Sternorrhyncha: Coccomorpha) of Poland (* alien established indoors only; ${ }^{* *}$ alien established outdoors; ${ }^{* * *}$ alien established indoors and outdoors.

\begin{tabular}{lc}
\hline \multicolumn{1}{c}{ Taxa } & Validation source \\
\hline Asterolecaniidae & \\
1. Asterodiaspis quercicola (Bouché, 1851) & Boratyński 1961 \\
2. Asterodiaspis variolosa (Ratzeburg, 1870) & Wünn 1919 \\
3. Asterolecanium epidendri (Bouché, 1844)* & Kawecki 1985 \\
4. Planchonia arabidis Signoret, 1876 & Komosińska and Podsiadło 1967 \\
Cerococcidae & \\
5. Antecerococcus intermedius (Balachowsky, 1930) & Koteja 1984 \\
Coccidae & \\
6. Ceroplastes rusci (Linnaeus, 1758)* & \\
7. Coccus hesperidum Linnaeus, 1758* & Szulczewski 1926 \\
8. Eriopeltis festucae (Fonscolombe, 1834) & Brischke 1883 \\
9. Eriopeltis lichtensteini Signoret, 1877 & Szulczewski 1921 \\
10. Eriopeltis stammeri Schmutterer, 1952 & Szulczewski 1921 \\
11. Eucalymnatus tessellatus (Signoret, 1873)* & Komosińska and Podsiadło 1967 \\
12. Eulecanium ciliatum (Douglas, 1891) & Koteja 1972 \\
13. Eulecanium douglasi (Šulc, 1895) & Wünn 1919 \\
14. Eulecanium franconicum (Lindinger, 1912) & Żak-Ogaza 1961 \\
15. Eulecanium sericeum (Lindinger, 1906) & Kawecki 1938 \\
16. Eulecanium tiliae (Linnaeus, 1758) & Kawecki 1938 \\
\end{tabular}




\begin{tabular}{l} 
Taxa \\
\hline 17. Lecanopsis formicarum Newstead, 1893 \\
18. Lecanopsis subterranea (Gomez-Menor Ortega, 1948) \\
19. Luzulaspis dactylis Green, 1928 \\
20. Luzulaspis frontalis Green, 1928 \\
21. Luzulaspis grandis Borchsenius, 1952 \\
22. Luzulaspis luzulae (Dufour, 1864) \\
23. Luzulaspis nemorosa Koteja, 1966 \\
24. Luzulaspis scotica Green, 1926 \\
25. Nemolecanium graniforme (Wünn, 1921) \\
26. Palaeolecanium bituberculatum (Signoret, 1873) \\
27. Parafairmairia bipartita (Signoret, 1872) \\
28. Parafairmairia gracilis Green, 1916 \\
29. Parasaissetia nigra (Nietner, 1861)* \\
30. Parthenolecanium corni (Bouché, 1844) \\
31. Parthenolecanium fletcheri (Cockerell, 1893)** \\
32. Parthenolecanium perlatum (Cockerell, 1898)* \\
33. Parthenolecanium persicae (Fabricius, 1776)
\end{tabular}

34. Parthenolecanium pomeranicum (Kawecki, 1954) 35. Parthenolecanium rufulum (Cockerell, 1903) 36. Parthenolecanium smreczynskii (Kawecki, 1967) 37. Phyllostroma myrtilli (Kaltenbach, 1874)

38. Physokermes hemicryphus (Dalman, 1826)

39. Physokermes piceae (Schrank, 1801)

40. Psilococcus ruber Borchsenius, 1952

41. Pulvinaria floccifera (Westwood, 1870)***

42. Pulvinaria hydrangeae Steinweden, $1946^{* *}$

43. Pulvinaria regalis Canard, 1968

44. Pulvinaria vitis (Linnaeus, 1758)

45. Saissetia coffeae (Walker, 1852)*

46. Saissetia oleae (Olivier, 1791)*

47. Sphaerolecanium prunastri (Fonscolombe, 1834)

48. Vittacoccus longicornis (Green, 1916)

\section{Cryptococcidae}

49. Cryptococcus fagisuga Lindinger, 1936

50. Pseudochermes fraxini (Kaltenbach, 1860)

\section{Diaspididae}

51. Aonidia lauri (Bouché, 1833)*

52. Aonidiella aurantii (Maskell, 1879)*

53. Aspidiotus destructor Signoret, $1869^{*}$

54. Aspidiotus nerii Bouché, 1833*

55. Aspidiotus palmarum Bouché, 1834*

56. Aulacaspis rosae (Bouché, 1833)**

57. Aulacaspis yasumatsui Takagi, 1977*

58. Carulaspis juniperi (Bouché, 1851)

59. Chionaspis salicis (Linnaeus, 1758)

60. Chrysomphalus aonidum (Linnaeus, 1758)*

61. Chrysomphalus dictyospermi (Morgan, 1889)*

62. Comstockaspis perniciosa (Comstock, 1881)**

63. Diaspidiotus alni (Marchal, 1909)

64. Diaspidiotus bavaricus (Lindinger, 1912)

65. Diaspidiotus gigas (Thiem \& Gerneck, 1934)

66. Diaspidiotus marani (Zahradnik, 1952)

67. Diaspidiotus ostreaeformis (Curtis, 1843)

\author{
Validation source \\ Koteja 1969 \\ Koteja and Żak-Ogaza 1969 \\ Żak-Ogaza and Koteja 1964 \\ Koteja 1964 \\ Żak-Ogaza and Koteja 1964 \\ Kawecki 1938 \\ Koteja 1966 \\ Komosińska and Podsiadło 1967 \\ Wünn 1919 \\ Kawecki 1935 \\ Żak-Ogaza and Koteja 1964 \\ Koteja and Żak-Ogaza 1969 \\ Kawecki 1985 \\ Lindinger 1911 \\ Kawecki 1935 \\ Dziedzicka and Madro 1999
}

Ruszkowski 1922 (recognized as a doubtful species by Kawecki (1985) and confirmed in Poland by Łagowska (2005a))

Kawecki 1954

Kawecki 1957

Kawecki 1967

Kawecki 1957

Wünn 1919

Kawecki 1935

Koteja 1969

Koteja 1972

Łagowska (unpublished)

Łagowska et al. 2018

Szulczewski 1921

Szulczewski 1926

Czyżewski 1937

Kawecki 1957

Koteja 1969

Szulczewski 1921

Szulczewski 1926

Komosińska 1968

Dziedzicka 1988b

Karnkowski 1993

Ruszkowski 1933

Schander 1910

Trzebiński 1916

Łabanowski 2009

Szulczewski 1926

Wünn 1919

Czyżewski 1937

Dziedzicka 1989

Kawecki 1950

Kawecki 1935 (recognized as a doubtful species by Kawecki

(1985) and confirmed in Poland by Łagowska (2002)

Kawecki 1948

Komosińska 1974

Krzysztofowicz 1957

Szulczewski 1921 


\begin{tabular}{|c|c|}
\hline Taxa & Validation source \\
\hline 68. Diaspidiotus pyri (Lichtenstein, 1881) & Szulczewski 1921 \\
\hline 69. Diaspidiotus zonatus (Fauenfeld, 1868) & Szulczewski 1921 \\
\hline 70. Diaspis boisduvalii Signoret, $1869^{*}$ & Czyżewski 1975 \\
\hline 71. Diaspis bromeliae (Kerner, 1778)* & Kawecki 1985 \\
\hline 72. Diaspis echinocacti (Bouché, 1883)* & Czyżewski 1937 \\
\hline 73. Dynaspidiotus abietis (Schrank, 1776) & Kawecki 1935 \\
\hline 74. Dynaspidiotus britannicus (Newstead, 1898)* & Szulczewski 1926 \\
\hline 75. Furchadaspis zamiae (Morgan, 1890) * & Komosińska 1968 \\
\hline 76. Gymnaspis aechmeae Newstead, 1898* & Komosińska 1961 \\
\hline 77. Hemiberlesia cyanophylli (Signoret, 1869) * & Komosińska 1961 \\
\hline 78. Hemiberlesia gliwicensis (Komosińska, 1965)* & Komosińska 1965 \\
\hline 79. Hemiberlesia lataniae (Signoret, 1869)* & Czyżewski 1937 \\
\hline 80. Hemiberlesia palmae (Cockerell, 1892)* & Komosińska 1961 \\
\hline 81. Hemiberlesia rapax (Comstock, 1881)* & Komosińska 1961 \\
\hline 82. Howardia biclavis (Comstock, 1883)* & Dziedzicka 1987 \\
\hline 83. Kuwanaspis pseudoleucaspis (Kuwana, 1902)* & Komosińska 1968 \\
\hline 84. Lepidosaphes conchiformis (Gmelin, 1790) & Komosińska 1969 \\
\hline 85. Lepidosaphes juniperi (Lindinger, 1912) & Komosińska 1969 \\
\hline 86. Lepidosaphes newsteadi (Šulc, 1895) & Komosińska 1974 \\
\hline 87. Lepidosaphes tokionis (Kuwana, 1902)* & Łabanowski 2009 \\
\hline 88. Lepidosaphes ulmi (Linnaeus, 1758) & Trzebiński 1916 \\
\hline 89. Leucaspis loewi Colvée, 1882 & Szulczewski 1921 \\
\hline 90. Leucaspis pini (Hartig, 1839) & Szulczewski 1921 \\
\hline 91. Parlatoria parlatoriae (Šulc, 1895)* & Żak-Ogaza and Koteja 1964 \\
\hline 92. Parlatoria pergandii Comstock, $1881^{*}$ & Komosińska 1964 \\
\hline 93. Parlatoria proteus (Curtis, 1843)* & Szulczewski 1926 \\
\hline 94. Pinnaspis aspidistrae (Signoret, 1869)* & Szulczewski 1926 \\
\hline 95. Pinnaspis strachani (Cooley, 1899)* & Komosińska 1961 \\
\hline 96. Pseudaulacaspis pentagona (Targioni-Tozzetti, 1886)* & Dziedzicka and Karnkowski 1999 \\
\hline 97. Rhizaspidiotus canariensis (Lindinger, 1911) & Łagowska 1990 \\
\hline 98. Umbaspis regularis (Newstead, 1911)* & Komosińska 1968 \\
\hline
\end{tabular}

\section{Eriococcidae}

99. Acanthococcus aceris Signoret, 1875

100. Acanthococcus macedoniensis Fetykó \& Kaydan, 2013

101. Anophococcus agropyri (Borchsenius, 1949)

102. Anophococcus confusus (Danzig, 1962)

103. Anophococcus herbaceus (Danzig, 1962)

104. Anophococcus inermis (Green, 1915)

105. Anophococcus insignis (Newstead, 1891)

106. Anophococcus pseudinsignis (Green, 1921)

107. Gossyparia spuria (Modeer, 1778)

108. Greenisca brachypodii Borchsenius \& Danzig, 1966

109. Greenisca gouxi (Balachowsky, 1954)

110. Kaweckia glyceriae (Green, 1921)

111. Neokaweckia laeticoris (Tereznikova, 1965)

112. Rhizococcus cantium (Williams, 1985)

113. Rhizococcus devoniensis Green,1896

114. Rhizococcus greeni (Newstead, 1898)

115. Rhizococcus munroi (Boratyński, 1962)

116. Rhizococcus palustris Dziedzicka \& Koteja, 1971

\section{Kermesidae}

117. Kermes quercus (Linnaeus, 1758)

118. Kermes roboris (Fourcroy,1785)

\section{Margarodidae}

119. Neomargarodes festucae Archangelskaja, 1935

\section{Kawecki 1957}

Kozár et al. 2013

Koteja and Żak-Ogaza 1966 Koteja 1971a

Żak-Ogaza and Koteja 1964

Żak-Ogaza and Koteja 1964

Żak-Ogaza and Koteja 1964

Koteja and Żak-Ogaza 1969 Trzebiński 1916

Koteja and Żak-Ogaza 1966

Koteja and Żak-Ogaza 1983

Żak-Ogaza and Koteja 1964

Koteja and Żak-Ogaza 1989

Łagowska and Koteja 1996

Koteja and Żak-Ogaza 1979

Żak-Ogaza and Koteja 1964

Komosińska and Podsiadło 1967

Dziedzicka and Koteja 1971

Szulczewski 1921

Koteja and Żak-Ogaza 1983

Jakubski 1965 


\begin{tabular}{l} 
Taxa \\
\hline 120. Porphyrophora polonica (Linnaeus, 1758) \\
Matsucoccidae \\
121. Matsucoccus pini (Green, 1925) \\
Monophlebidae \\
122. Icerya purchasi Maskell, 1879* \\
123. Palaeococcus fuscipennis (Burmeister, 1835) \\
Steingeliidae
\end{tabular}

124. Steingelia gorodetskia Nasonov, 1908

\section{Xylococcidae}

125. Xylococcus filiferus Löw, 1883

\section{Ortheziidae}

126. Arctorthezia cataphracta (Olafson, 1772)

127. Newsteadia floccosa (De Geer, 1778)

128. Insignorthezia insignis (Browne, 1887)*

129. Orthezia urticae (Linnaeus, 1758)

130. Ortheziola vejdovskyi Šulc, 1895

\section{Pseudococcidae}

131. Atrococcus cracens Williams, 1962

132. Atrococcus paludinus (Green, 1921)

133. Balanococcus boratynskii Williams, 1962

134. Boreococcus ingricus Danzig, 1960

135. Brevennia pulveraria (Newstead, 1892)

136. Ceroputo pilosellae Šulc, 1898

137. Chaetococcus sulcii (Green, 1934)

138. Coccura comari (Künow, 1880)

139. Dysmicoccus angustifrons (Hall, 1926)

140. Dysmicoccus walkeri (Newstead, 1891)

141. Fonscolombia abdita (Borchsenius, 1949)

142. Fonscolombia europaea (Newstead, 1897)

143. Fonscolombia tomlinii (Newstead, 1892)

144. Heliococcus bohemicus Sulc, 1912

145. Heliococcus destructor Borchsenius, 1941

146. Heliococcus sulcii Goux, 1934

147. Heterococcus nudus (Green, 1926)

148. Kiritshenkella lianae Koteja, 1988

149. Metadenopus festucae Šulc, 1933

150. Mirococcopsis subterranea (Newstead, 1893)

151. Mirococcus clarus Borchsenius, 1949

152. Mirococcus festucae Koteja, 1971

153. Nipaecoccus nipae (Maskell, 1893)*

154. Peliococcopsis parviceraria (Goux, 1937)

155. Peliococcus calluneti (Lindinger, 1912)

156. Peliococcus morrisoni (Kiritchenko, 1936)

157. Pelionella balteata (Green, 1928)

158. Pelionella manifecta (Borchsenius, 1949)

159. Phenacoccus aceris (Signoret, 1875)

160. Phenacoccus hordei (Lindeman, 1886)

161. Phenacoccus interruptus Green, 1923

162. Phenacoccus phenacoccoides (Kiritchenko, 1932)

163. Phenacoccus piceae (Löw, 1883)

164. Planococcus citri (Risso, 1813)*

165. Planococcus vovae (Nasonov, 1908)

166. Pseudococcus longispinus (Targioni Tozzetti, 1867)*

167. Pseudococcus maritimus (Ehrhorn, 1900)*

168. Rhodania occulta Schmutterer, 1952

\section{Validation source}

Miechowita 1521

Boratyński 1960

Chałańska and Łabanowski 2002 Szulczewski 1921

\section{Nasonov 1908}

Kawecki 1948

Kawecki 1938

Kawecki 1938

Ruszkowski 1933

Nowicki 1868

Komosińska and Podsiadło 1967

Koteja 1971a

Koteja 1971a

Koteja 1986

Koteja 1986

Żak-Ogaza and Koteja 1964

Kawecki 1948

Koteja and Żak-Ogaza 1969

Koteja et al. 1978

Koteja and Żak-Ogaza1979

Komosińska and Podsiadło 1967

Koteja 1971a

Koteja and Żak-Ogaza 1969

Koteja 1972

Komosińska 1977

Koteja et al. 1978

Łagowska and Koteja 1996

Żak-Ogaza and Koteja 1964

Koteja 1988

Koteja and Żak-Ogaza 1969

Koteja and Żak-Ogaza1969

Koteja 1971b

Koteja 1971b

Czyżewski 1937

Koteja et al. 1978

Koteja and Żak-Ogaza1966

Łagowska 2005b

Koteja 1972

Koteja and Żak-Ogaza1989

Wünn 1919

Koteja and Żak-Ogaza 1979

Żak-Ogaza and Koteja 1964

Łagowska and Koteja 1996

Kawecki 1935

Szulczewski 1926

Kawecki 1948

Szulczewski 1926

Dziedzicka 1988a

Koteja and Żak-Ogaza1966 


\begin{tabular}{|c|c|}
\hline Taxa & Validation source \\
\hline 169. Rhodania porifera Goux, 1935 & Koteja and Żak-Ogaza1969 \\
\hline 170. Saccharicoccus isfarensis (Borchsenius, 1949) & Koteja 1969 \\
\hline 171. Spilococcus mamillariae (Bouchè, 1844)* & Łabanowski 2009 \\
\hline 172. Trionymus aberrans Goux, 1938 & Koteja and Żak-Ogaza 1966 \\
\hline 173. Trionymus hamberdi (Borchsenius, 1949) & $\begin{array}{l}\text { Danzig } 1985 \text { (confirmed in Poland by Łagowska and Koteja } \\
\text { (1996)) }\end{array}$ \\
\hline 174. Trionymus newsteadi (Green, 1917) & Koteja and Żak-Ogaza1966 \\
\hline 175. Trionymus perrisii (Signoret, 1875) & Koteja 1969 \\
\hline 176. Trionymus phalaridis Green, $1925 \mathrm{n}$ & Komosińska 1980 \\
\hline 177. Trionymus placatus (Borchsenius, 1949) & Koteja and Łagowska 1986 \\
\hline 178. Trionymus radicum (Newstead, 1895 ) & Koteja 1971a \\
\hline 179. Trionymus thulensis Green, 1931 & Koteja 1969 \\
\hline 180. Volvicoccus volvifer Goux, 1945 & Kalandyk and Węgierek 2010 \\
\hline \multicolumn{2}{|l|}{ Putoidae } \\
\hline 181. Puto superbus (Leonardi, 1907) & Łagowska 2000 \\
\hline \multicolumn{2}{|l|}{ Rhizoecidae } \\
\hline 182. Rhizoecus americanus (Hambleton, 1946)* & Łabanowski 2009 \\
\hline 183. Rhizoecus cacticans (Hambleton, 1946)* & Kawecki 1985 \\
\hline 184. Rhizoecus dianthi Green, $1926^{*}$ & Dziedzicka and Madro 1999 \\
\hline 185. Ripersiella halophila (Hardy, 1868) & Koteja 1972 \\
\hline
\end{tabular}

Table 2. Number of scale insect species per genus in relation to families in Poland.

\begin{tabular}{lccc}
\hline \multicolumn{1}{c}{ Family } & Number of genus & Number of species & Ratio of species to genera \\
\hline Asterolecaniidae & 3 & 4 & $1.3: 3$ \\
Cerococcidae & 1 & 1 & $1: 1$ \\
Coccidae & 19 & 43 & $2.3: 1$ \\
Cryptococcidae & 2 & 2 & $1: 1$ \\
Diaspididae & 23 & 48 & $2.0: 1$ \\
Eriococcidae & 7 & 18 & $2.6: 1$ \\
Kermesidae & 1 & 2 & $2.0: 1$ \\
Margarodidae & 2 & 2 & $1: 1$ \\
Matsucoccidae & 1 & 1 & $1: 1$ \\
Monophlebidae & 2 & 2 & $1: 1$ \\
Steingeliidae & 1 & 1 & $1: 1$ \\
Xylococcidae & 1 & 1 & $1: 1$ \\
Ortheziidae & 5 & 5 & $1: 1$ \\
Pseudococcidae & 27 & 50 & $1.8: 1$ \\
Putoidae & 1 & 1 & $1: 1$ \\
Rhizoecidae & 2 & 4 & $2.0: 1$ \\
\multicolumn{1}{c}{ All scale families } & 98 & 185 & $1.9: 1$ \\
\hline
\end{tabular}

Of the 185 species present in Poland, 133 (71.9\%) are native (Figure 1). The alien scale insect species number 52 (28.1\% of total); these species clearly dominate over the native ones in the Diaspididae family, while the remaining families are represented by 1-10 alien species or only by native species (Figure 1). Of the 52 alien species known in Poland, 47 can develop only indoors, while five, namely Aulacaspis rosae, Comstockaspis perniciosa, Parthenolecanium fletcheri, Pulvinaria floccifera, and $P$. hydrangeae, overwinter and develop outdoors. Pulvinaria floccifera develops both indoors and outdoors (Table 1). 


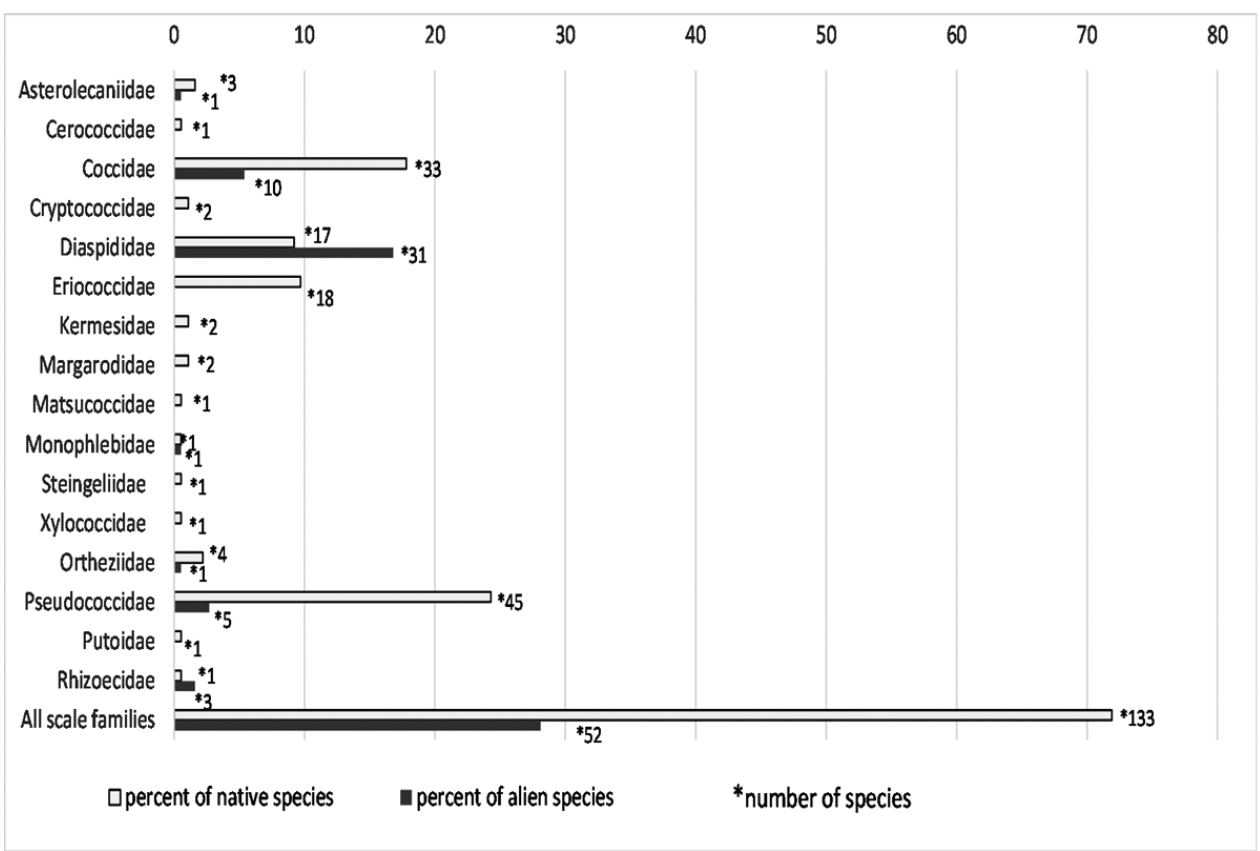

Figure I. Native and alien scale insect species in different families in Poland.

\section{Discussion}

The scale insect species recorded in Poland represent only ca. $7.3 \%$ of the 2536 species known in the Palearctic region (García Morales et al. 2016) and ca. $41.1 \%$ of the 450 species reported in Europe (Pellizzari and Germain 2010). The previous checklist of scale insects of Poland was published 15 years ago (Łagowska 2004) and listed 185 species distributed in nine families and 94 genera. In the present list, the families Cryptococcidae, Matsucoccidae, Monophlebidae, Steingeliidae, Xylococcidae, Putoidae, and Rhizoecidae have been added, using the currently accepted classification of Coccomorpha. Moreover, eleven species new for the country have been added and ten species removed. The new entries are: Asterodiaspis quercicola, Pulvinaria hydrangeae, P. regalis, Aspidiotus palmarum, Aulacaspis yasumatsui, Lepidosaphes tokionis, Acanthococcus macedoniensis, Icerya purchasi, Spilococcus mamillariae, Volvicoccus volvifer, and Rhizoecus americanus. Of these $V$. volvifer, $P$. hydrangeae, $P$. regalis, and $A$. macedoniensis are established outdoors (Kalandyk and Węgierek 2010; Kozár et al. 2013; Łagowska et al. 2018), whereas A. yasumatsui, L. tokionis, S. mamillariae, and $R$. americanus, are indoors species (Eabanowski 2009). Icerya purchasi and A. palmarum were overlooked in the previous checklist and are therefore added to the present one. Asterodiaspis quercicola is here considered as a valid species (García Morales et al. 2016), despite the fact that Podsiadło (1990) and Stumpf and Lambdin (2006) considered A. quercicola and A. variolosa as synonyms.

Of the ten species removed from the list, six have been synonymized with other species (Eulecanium slavum (Kawecki, 1961), Lepidosaphes oleae Leonardi, 1908, Heliococcus danzigae Bazarov, 1974, Trionymus isfarensis Borchsenius, 1949, 
T. singularis Schmutterer, 1952, and Phenacoccus evelinae Tereznikova, 1975). The presence in Poland of the other four species removed from the list, Ripersia corynephori Signoret, 1875, Carulaspis visci (Schrank, 1781), Fiorinia fioriniae (TargioniTozzetti, 1867) and Oceanaspidiotus spinosus (Comstock, 1883) is here considered as doubtful or erroneous. Kiritchenko (1940) listed $R$. corynephori as found near Warsaw, but Kawecki (1985) assumed that this record was incorrect and the species might be a misidentification of Pseudococcus parvus Borchsenius, 1949 (now Mirococcopsis subterranea (Newstead, 1893)). Similarly, the record of C. visci was very likely incorrect and the species may be a misidentification of Carulaspis juniperi (Bouchè, 1851). In addition, the records of $F$ f fioriniae and O. spinosus are questionable because no host plants or localities were given in the list published by Czyżewski (1937). All the species mentioned above have not been collected again since they were first recorded.

Based on the distribution data reported by Łagowska (2001), the native species currently known from Poland are all Palearctic. Almost half of them are widely distributed in this region, and relatively few are known only from three or four countries. This latter group includes the following species: Anophococcus confusus, Rhizococcus cantium, Boreococcus ingricus, Mirococcus festucae, and A. macedoniensis. Two species, Parthenolecanium smreczynskii and Kiritshenkella lianae, are known so far only from Poland and are possibly endemic.

Recently, much attention has been paid to the alien species of scale insects that have been introduced or have spread into Poland. This group includes 47 indoor and five outdoor species. One species (P. floccifera) has been recorded on ornamental plants in greenhouses in Poland as well as on outdoor ornamentals, mostly on Ilex sp., and appears to be established (Łagowska et al. 2017). Of the 47 species established indoors, 29 (61.7\%) belong to the Diaspididae. This high proportion of species from Diaspididae family introduced into Poland is similar to the results presented by Pellizzari and Germain (2010) for Europe. According to these authors, the 60 alien species belonging to the Diaspididae account for nearly half (44.6\%) of the 130 alien species estimated to occur in Europe. Of the five alien species established outdoors in Poland, only C. perniciosa and P. floccifera are considered as invasive (Łagowska et al. 2017, 2018). Currently, C. perniciosa poses the greatest threat, affecting a number of fruit trees in Poland (Golan et al. 2017).

Some differences in the species richness were found between the data reported in the databases ScaleNet and FaEu and the present checklist. Scale insects that are erroneously recorded as present in Poland in the above recorded databases are discussed below:

\section{Antecerococcus cistarum (Balachowsky, 1927), A. laniger (Goux, 1932), and $A$. pocilliferus (Neves, 1954)}

The presence of these three species in Poland, cited by the ScaleNet database, is a misunderstanding of the text of Koteja (1984), which records them as present in several European countries (Portugal, France, Algeria, Cyprus) but not in Poland. These three 
species were not listed by any of the researchers studying the fauna of scale insects in Poland, so they are excluded from the present list. The same species have also been incorrectly recorded in the $\mathrm{FaEu}$ database.

\section{Asterodiaspis minor (Russell, 1941)}

This species was recorded by Russell (1941) in Poland, but Podsiadło (1975) recognized only Asterodiaspis quercicola and $A$. variolosa in Poland based on extensive morphological studies. Since this time, A. minor was not listed in the subsequent publications pertaining to the fauna of scale insects in Poland and is excluded from the present list, although it is listed in the ScaleNet database.

\section{Epidiaspis leperii (Signoret, 1869)}

In the ScaleNet database Poland is included among the locations of distribution of this species based on the paper of Danzig and Pellizzari (1998). However, the paper does not provide any precise indication of its presence in Poland. The species was also not listed later by the researchers who studied the fauna of scale insects in Poland, so it is excluded from the present list.

\section{Kermes bacciformis Leonardi, 1908 and Kermes ilicis (Linnaeus, 1758)}

These two species are recorded as hosts of a parasitoid by Sugonyaev (1965), and are cited by the ScaleNet database as records of distribution of scale insects, but this is probably a misunderstanding of the text, as the distribution records concern the parasitoid species and not the scale insects. These two species have also been incorrectly included in the FaEu database.

\section{Lecanopsis turcica (Bodenheimer, 1951)}

Poland was included among the countries in which this species is distributed in the FaEu database, but the source of information is missing. As there is no published evidence for the presence of this coccid in Poland, it is excluded from the present list.

\section{Leucaspis pusilla Löw, 1883}

This species is erroneously recorded in the ScaleNet catalogue citing Danzig and Pellizzari (1998), but those authors do not mention Poland as a location of its distribution. 


\section{Matsucoccus matsumurae (Kuwana, 1905)}

Poland was included among the countries where this species is present in the $\mathrm{FaEu}$ database, but the source of information is missing. As there is no evidence for the presence of this species in Poland, it is excluded from the present list.

\section{Parlatoria oleae (Colvee, 1880) and Parlatoria theae Cockerell, 1896}

These two species are recorded as present in Poland in the FaEu database with an incorrect citation of ScaleNet as the source of information. We have been unable to trace the original sources of publication concerning the presence of these species in Poland and therefore we consider these records erroneous.

\section{Parlatoria ziziphi (Lucas, 1853)}

This species is cited in ScaleNet based on Komosińska (1964). However, this species was only found on citrus fruits imported to Poland. Since P. ziziphi was not mentioned in subsequent papers, we assume that this species is not established in Poland.

\section{Pseudococcus viburni (Signoret, 1875)}

Poland was included among the countries in which this species is present in the $\mathrm{FaEu}$ database, but the source of information is missing. As there is no evidence of the presence of this mealybug in Poland, this species is excluded from the present list.

\section{Trionymus levis (Tang, 1992)}

Koteja (1974) and Koteja and Żak-Ogaza (1983) do not provide evidence of the presence of T. levis in Poland as cited by the ScaleNet database. Moreover, this species was not listed in the subsequent publications related to the Polish fauna of scale insects and is therefore removed from the present checklist. It has also been incorrectly included in the $\mathrm{FaEu}$ database.

\section{References}

Boratyński K (1960) Matsucoccus pini (Green) (Homoptera: Coccoidea, Margarodidae) in Norfolk. Entomologist's Monthly Magazine 93: 246-251.

Boratyński K (1961) A note on the species of Asterolecanium Targioni-Tozzeti, 1869 (Homoptera, Coccoidea, Asterolecaniidae) on oak in Britain. Proceedings of the 
Royal Entomological Society of London, Series B: Taxonomy 30: 4-14. https://doi. org/10.1111/j.1365-3113.1961.tb00435.x

Brischke CGA (1883) Beschreibung der forst-, garten- und landwirthschaftlichen Feinde und Freunde unter den Insekten. Schriften der Naturforschenden Gesellschaft in Danzig 5(4): 97-125.

Burckhardt D (2013) Fauna Europaea: Coccoidea. version 2017.06. https://fauna-eu.org [Accessed on 11.09.2019]

Chałańska A, Łabanowski G (2002) New and less known plant pests in greenhouses - part I. Hasło Ogrodnicze 5: 86-90. [In Polish]

Czyżewski JA (1937) The importance of plant diseases and pests in floriculture. Wiadomości Ogrodnicze 3: 15-18. [In Polish]

Czyżewski JA (1975) Plant Diseases and Pests in Floriculture. Warszawa, 666 pp. [In Polish]

Danzig EM (1985) Contribution to the scale insect fauna (Homoptera, Coccinea) of Teberda State Reserve. Entomologicheskoe Obozrenye 64: 110-123.

Danzig EM, Gavrilov-Zimin IA (2014) Palaearctic mealybugs (Homoptera: Coccinea: Pseudococcidae), Part 1: Subfamily Phenacoccinae. Russian Academy of Sciences, St. Petersburg, 678 pp.

Danzig EM, Gavrilov-Zimin I.A (2015) Palaearctic mealybugs (Homoptera: Coccinea: Pseudococcidae), Part 2: Subfamily Pseudococcinae. Russian Academy of Sciences, St. Petersburg, 619 pp. https://doi.org/10.31610/zsr/2015.24.2.236

Danzig EM, Pellizzari G (1998) Diaspididae. In: Kozár F (Ed.) Catalogue of Palaearctic Coccoidea. Hungarian Academy of Sciences, Budapest, 526 pp.

Dziedzicka A (1970) Materials for the study of scale insects (Coccoidea) occurring on Polish territory. Rocznik Naukowo-Dydaktyczny, WSP w Krakowie 37: 24-27. [In Polish with English summary]

Dziedzicka A (1987) Notes on the occurrence of rare species of greenhouse armored scale insects (Homoptera, Coccinea, Diaspididae) in Poland. Rocznik Naukowo-Dydaktyczny WSP w Krakowie 111: 143-150. [In Polish with English summary]

Dziedzicka A (1988a) Glass-house mealybugs (Homoptera, Coccinea, Pseudococcidae). Zeszyty Problemowe Postępów Nauk Rolniczych 333: 87-91. [In Polish]

Dziedzicka A (1988b) The greenhouses scale insects of Poland. Rocznik Naukowo-Dydaktyczny, WSP w Krakowie 123: 79-91. [In Polish with English summary]

Dziedzicka A (1989) Scale insects (Coccinea) occurring in Polish greenhouses. Part I. Diaspididae. Acta Biologica Cracoviensia, Series Zoologia 31: 93-114.

Dziedzicka A (1990a) The characteristic of scale insects (Coccinea) occurring in Polish greenhouses. Part II. Coccidae. Acta Biologica Cracoviensia, Series Zoologia 32: 17-27.

Dziedzicka A (1990b) The characteristic of scale insects (Coccinea) occurring in Polish greenhouses. Part III. Pseudococcidae. Acta Biologica Cracoviensia, Series Zoologia 32: 29-38.

Dziedzicka A, Karnkowski W (1999) White peach scale Pseudaulacaspis pentagona Targ.-Tozz. - potential threat to orchards and plantations of woody ornamental plants in Poland. Ochrona Roślin 43(8): 30-32. [In Polish]

Dziedzicka A, Koteja J (1971) A revision of the species of the genus Rhizococcus Signoret (Homoptera, Coccoidea) occurring in Poland. Acta Zoologica Cracoviensia 16: 557-579.

Dziedzicka A, Madro D (1999) Three species of scale insects (Coccinea) new to Polish greenhouses. Acta Biologica Cracoviensia; Series Zoologia 41: 15-18. 
García Morales M, Denno B, Miller DR, Miller GL, Ben-Dov Y, Hardy NB (2016) ScaleNet: a literature-based model of scale insect biology and systematics. http://scalenet.info [Accessed on 20.08.2019]

Golan K, Łagowska B, Kot I (2017) Comstockaspis perniciosa Comst. (Hemiptera; Coccomorpha; Diaspididae) again in Poland. $35^{\text {th }}$ National Hemipterological Conference, KatowiceKochcice (Poland), April 2017, 26. [In Polish]

Jakubski AW (1965) A critical revision of the families Margarodidae and Termitococcidae (Hemiptera, Coccoidea). Trustees of the British Museum (Natural History) London, $187 \mathrm{pp}$.

Kalandyk M, Węgierek P (2010) Scale Insects (Hemiptera, Sternorrhyncha, Coccoidea) of Selected Plant Communities in the Eastern Part of Garb Tarnogórski. Annals of the Upper Silesian Museum in Bytom - Entomology 19: 1-116.

Karnkowski W (1993) The occurrence of armored scales Aspidiotus destructor Signoret on dracaena plant. Wszechświat 94(5): 127-128. [In Polish]

Kawecki Z (1935) Scale insects (Coccidae) of the Krakow and Kielce provinces collected in 1933-1934. Sprawozdanie Komisji Fizjograficznej Polskiej Akademii Umiejętności 68/69: 73-90. [In Polish]

Kawecki Z (1938) The Coccidae of the Tatra Mountains. Sprawozdanie Komisji Fizjograficznej Polskiej Akademii Umiejętności 71: 199-208. [In Polish]

Kawecki Z (1948) A contribution to the knowledge of scale insects (Coccidae) of Poland. Some Coccidae from Poland. Materiały Fizjograficzne Kraju 10: 1-10. [In Polish]

Kawecki Z (1950) San José Scale - Quadraspidiotus (Aspidiotus) perniciosus Comst. in Europe and its appearance in Poland. Polska Akademia Umiejętności, Prace Rolniczo-Leśne 55: 1-54. [In Polish]

Kawecki Z (1954) Studies on the genus Lecanium Burm. II. The Yew Scale, Lecanium pomeranicum sp. n. and some related species (Homoptera, Coccoidea, Lecaniidae). Annales Zoologici 16: 9-22. [In Polish]

Kawecki Z (1957) Notes on scale insects (Homoptera, Coccoidea). Acta Zoologica Cracoviensia 2: 193-204. [In Polish]

Kawecki Z (1967) Studies on the genus Lecanium Burm. VI. Lecanium smreczynskii sp. n. (Homoptera, Coccoidea, Lecaniidae). Bulletin de l'Academie Polonaise des Sciences 15: 687-689.

Kawecki Z (1985) Scale insects, Coccoidea. Catalogue of Polish Fauna, Polish Academy, Zoological Institute 21: 1-108. [In Polish].

Kiritchenko A (1940) Tretie soobščenije o faunie kokcid (Coccoidea). Trudy Zoologicheskogo Instituta. Akademiia Nauk SSSR 6: 115-137.

Komosińska H (1961) On some scale-insects (Homoptera, Coccoidea) living in greenhouses in Poland. Fragmenta Faunistica 9: 221-232. [In Polish with English summary] https://doi. org/10.3161/00159301FF1961.9.15.221

Komosińska H (1964) Armored scale insects (Homoptera, Coccoidea, Diaspididae) of citrus fruits imported to Poland. Fragmenta Faunistica 11: 207-231. https://doi.org/10.3161/0 0159301FF1964.11.14.207

Komosińska H (1965) A new species of Abgrallaspis Balach. (Homoptera, Coccoidea, Diaspididae) from greenhouses in Poland. Frustula Entomologica 8(4): 1-6. 
Komosińska H (1968) Investigations on the scale insects (Homoptera, Coccoidea, Diaspididae) living in greenhouses in Poland. Part I. Polskie Pismo Entomologiczne 38: 205-208. [In Polish with English summary]

Komosińska H (1969) Studies of scale insects (Homoptera, Coccoidea, Diaspididae) of Poland, I. Fragmenta Faunistica 15: 267-271. [In Polish with English summary] https://doi.org/1 $0.3161 / 00159301 \mathrm{FF} 1969.15 .16 .267$

Komosińska H (1974) Physiographical and ecological investigations upon armored scale insects (Homoptera, Doccoidea, Diaspididae) of Poland. Zeszyty Naukowe AR w Warszawie. Rozprawy Naukowe 43: 1-84. [In Polish with English summary]

Komosińska H (1977) Materials to the knowledge of scale insects (Homoptera, Coccoidea) of the Kampinoski National Park. Sylwan 121(1): 21-24. [In Polish]

Komosińska H (1980) Trionymus luzensis sp. n. (Homoptera, Coccoidea, Pseudococcidae) from Poland. Annales Zoologici (Warsaw) 35: 257-265.

Komosińska H (1987) Occurrence of scale insects (Homoptera, Coccoidea) on trees and shrubs of the Warsaw parks. Annals of Warsaw Agricultural University - SGGW-AR (21): 95-103.

Komosińska H, Podsiadło E (1967) Materials to the fauna of scale insects (Homoptera, Coccoidea) steppe reservations in the Nida Valley (South Poland). I. Bulletin de l'Academie Polonaise des Sciences. Serie des Sciences Biologiques 15: 683-686.

Koteja J (1964) Notes on scale insects (Homoptera, Coccoidea) in Poland's fauna. Polskie Pismo Entomologiczne 34: 177-184. [In Polish with English summary]

Koteja J (1966) Luzulaspis nemorosa sp. n. (Homoptera, Coccoidea, Coccidae). Polskie Pismo Entomologiczne 36(3): 45-46.

Koteja J (1969) Notes on the Poland's scale insect fauna (Homoptera, Coccoidea). II. Polskie Pismo Entomologiczne 39: 3-15.

Koteja J (1971a) Notes on the Polish scale insect fauna (Homoptera, Coccoidea). III. Polskie Pismo Entomologiczne 41: 319-326. [In Polish with English summary]

Koteja J (1971b) Two new species of Micrococcus Borchsenius (Homoptera, Coccoidea, Pseudococcidae). Polskie Pismo Entomologiczne 42: 565-571.

Koteja J (1972) Notes on the Polish scale insect fauna (Homoptera, Coccoidea) IV. Polskie Pismo Entomologiczne 42(3): 565-571.

Koteja J (1974) The occurrence of a campaniform sensillum on the tarsus in the Coccinea (Homoptera). Polskie Pismo Entomologiczne 44: 243-252.

Koteja J (1984) Cerococcus cycliger (Goux) (Homoptera, Coccinea) new to the Polish Fauna. Polskie Pismo Entomologiczne 54: 413-414.

Koteja J (1985) Faunistic investigations on scale insects Coccinea (Homoptera, Coccinea) in Poland. Wiadomości Entomologiczne 6: 11-26. [In Polish]

Koteja J (1986) Notes on the Polish scale insect fauna (Homoptera, Coccinea) VI. Polskie Pismo Entomologiczne 56: 217-219.

Koteja J (1988) Review of Kiritshenkella Borchsenius and Balanococcus Williams, with a description of a new species (Homoptera, Pseudococcidae). Annales Zoologici 42: 119-163.

Koteja J (1996) How to recognize scale insects (Homoptera, Coccinea). In: Boczek J (Ed.) Diagnosis of plant pests and their natural enemies. SGGW Warszawa, 2: 139-231. [In Polish] 
Koteja J (2000) Scale insects (Sternorrhyncha: Coccoidea) from the Bieszczady Mountains. Monografie Bieszczadzkie 7: 241-244.

Koteja J, Łagowska B (1986) Dysmicoccus balticus sp. n. (Homoptera, Coccinea, Pseudococcidae). Polskie Pismo Entomologiczne 56: 381-388.

Koteja J, Żak-Ogaza B (1966) Investigations on scale insects (Homoptera, Coccidea) of the Pieniny Klippen Belt. Acta Zoologica Cracoviensia 11: 305-332.

Koteja J, Żak-Ogaza B (1969) The scale insect fauna (Homoptera, Coccidea) of the Ojców National Park in Poland. Acta Zoologica Cracoviensia 14: 351-373.

Koteja J, Żak-Ogaza B (1979) Five species of Pseudococcidae and Eriococcidae (Homoptera) new to the Polish fauna. Polskie Pismo Entomologiczne 49: 671-675.

Koteja J, Żak-Ogaza B (1983) The Coccinea fauna (Homoptera) of the Kraków-Czestochowa Upland (southern Poland). Acta Zoologica Cracoviensia 26: 465-490. [In Polish with English summary]

Koteja J, Żak-Ogaza B (1989) Scale insects (Homoptera: Coccinea) of the Swietokrzyskie Mountains. Fragmenta Faunistica 32: 19-34. [In Polish with English summary] https:// doi.org/10.3161/00159301FF1989.32.12.243

Koteja J, Żak-Ogaza B, El-Nabawi A (1978) Notes on Heterococcus Ferris and four mealybugs (Homoptera, Pseudococcidae) new to the Polish fauna. Polskie Pismo Entomologiczne 48: 501-540.

Kozár F, Kaydan MB, Konczné Benedicty Z, Szita É (2013) Acanthococcidae and related families of the Palaearctic Region. Hungarian Academy of Sciences, Budapest, Hungary, 680 pp.

Krzysztofowicz A (1957) A contribution to the knowledge of Polish scale insect fauna (Homoptera, Coccoidea, Aspidiotini). Zeszyty Naukowe Uniwersytetu Jagiellońskiego 10: 223-240. [In Polish]

Lindinger L (1911) Beiträge zur Kenntnis der Schildläuse und ihre Verbreitung II. Zeitschrift für Wissenschaftliche Insektenbiologie 7: 9-12, 86-90, 126-130, 172-177.

Łabanowski G (2009) Pests of ornamental plants introduced to Polish glasshouses. Progress in Plant Protection 49(4): 1714-1723.

Łagowska B (1990) Rhizaspidiotus canariensis (Lindinger) (Homoptera, Diaspididae) new to the Polish fauna. Polskie Pismo Entomologiczne 60: 261-263.

Łagowska B (2000) Puto superbus (Leonardi, 1907) (Homoptera: Pseudococcidae) new to the Polish fauna. Polskie Pismo Entomologiczne 69: 3-6.

Łagowska B (2001) Zoogeographical analysis of the scale insect fauna of Poland. Bollettino di Zoologica Agraria e di Bachicoltura Ser. II, 3(3): 239-248.

Łagowska B (2002) New data on the occurrence of Diaspidiotus alni (Marchal, 1909) (Hemiptera: Coccoidea: Diaspididae) in Poland. Wiadomości Entomologiczne 20(3-4): 184. [In Polish]

Łagowska B (2004) Species checklist. Sternorrhyncha, scale insects (Coccoidea). In: Bogdanowicz W, Chudzicka E, Pilipiuk I, Skibińska E (Eds) Fauna of Poland - Characteristics and checklist of species. Tom I . Wyd. Muzeum i Instytut Zoologii PAN, Warszawa, 266-269. [In Polish] Łagowska B (2005a) New data on the occurrence and morphological variability of Parthenolecanium persicae (Fabricius, 1776) (Hemiptera: Coccidae) in Poland. Wiadomości Entomologiczne 24 (1): 5-10. [In Polish with English summary] 
Łagowska B (2005b) Spinococcus morrisoni (Kiritchenko, 1936) (Hemiptera: Pseudococcidae) new to the fauna of Poland. Polskie Pismo Entomologiczne 74: 39-42.

Łagowska B (unpublished) New record and data on Pulvinaria species (Hemiptera, Coccomorpha, Coccidae) from Poland. Polish Journal of Entomology.

Łagowska B, Golan K (2005) The condition of faunistic research on scale insects (Hemiptera, Coccinea) in Poland. Aphids and other Hemipterous insects. Monograph 11. Agricultural University Publisher, Poznań, 107-116.

Łagowska B, Koteja J (1996) Scale insects (Homoptera, Coccinea) of Roztocze. Fragmenta Faunistica 39: 29-42. [In Polish with English summary] https://doi.org/10.3161/001593 01FF1996.39.4.029

Łagowska B, Golan K, Kot I, Kmieć K, Górska-Drabik E, Goliszek K (2015) Alien and invasive scale insect species in Poland and their threat to native plants. Bulletin of Insectology 68(1): 13-22.

Łagowska B, Golan K, Kmieć K, Kot I, Górska-Drabik E, Goliszek K (2017) The phenology of Pulvinaria floccifera Westwood (Hemiptera: Coccomorpha: Coccidae), a new invasive pest on ornamentals outdoors in Poland. Turkish Journal of Zoology 41: 113-118.

Łagowska B, Golan K, Michalski M (2018) First record of Pulvinaria regalis Canard, 1968 (Hemiptera: Coccomorpha: Coccidae) in Poland. Polish Journal of Entomology 87(4): 371-378. https://doi.org/10.2478/pjen-2018-0025

Miechowita M (1521) Chronica polonorum. Cracoviae, cap. 3: III.

Minkiewicz S (1926) Checklist of major pests on crops in Poland. 2: 1-9. [In Polish]

Nasonov NV (1908) Steingelia gorodetskia, nov. gen. et nov. sp. nouveau genre et espèce des coccides du groupe Xylococcini. [New genus and species of coccids from the group Xylococcini.]. Annuaire du Musée Zoologique de l'Académie Impériale des Sciences de St. Pétersbourg 13: 345-352.

Nowicki M (1868) Checklist of bugs (Rhynchota F., Hemiptera L.). Sprawozdania Komisji Fizyograficznej Kraków 2: 91-107.

Pellizzari G, Germain JF (2010) Scales (Hemiptera, Superfamily Coccoidea. In: Roques A, Kenis M, Leeds D, Lopez-Vaamonde C, Rabitsch W, Rasplus JY, Roy DB (Eds) Alien terrestrial arthropods of Europe. Pensoft Publishers, Sofia, Bulgaria. BioRisks 4(1): 475-510. https://doi.org/10.3897/biorisk.4.45

Podsiadło E (1975) Studies on the identification and occurrence of species of the genus asterodiaspis Signoret, 1876 (Homoptera, Coccoidea, Asterolecaniidae). Przegląd Zoologiczny 19(2): 211-216. [In Polish with English summary]

Podsiadło E (1990) Concept of the species of Asterodiaspis variolosa (Ratzeburg, 1870) (Homoptera, Coccoidea, Asterolecaniidae). Annales Zoologici 43(18): 363-371.

Podsiadło E, Komosińska H (1976) Further investigations on the scale insect fauna (Homoptera, Coccoidea) in the Nida Valley (Southern Poland). Bulletin de l'Academie Polonaise des Sciences. Serie des Sciences Biologiques 24: 87-91.

Russell LM (1941) A classification of the scale insect genus Asterolecanium. United States Department of Agriculture, Miscellaneous Publications 424: 1-319. https://doi.org/10.5962/ bhl.title.65621 
Ruszkowski J W (1922) Animal pests of fruit orchards around Poznań observed in 1921. Ziemianin, Poznań 73: 264-270. [In Polish]

Ruszkowski JW (1925) Pests in orchards around Poznań in 1922. Choroby i Szkodniki Roślin 1(1): 32-36. [In Polish]

Ruszkowski JW (1933) Research results on harmful Polish fauna based on materials from 1919-1930. Roczniki Ochrony Roślin 1(1-3): 1-567. [In Polish]

Schander R (1910) Bericht über das Auftreten von Krankheiten und tierischen Schädlingen an Kulturpflanzen in den Provinzen Posen und Westpreußen für das Jahr 1908. Mitt. K. Wilh. Inst. Landw. Bromberg 2: 148.

Stumpf CF, Lambdin PL (2006) Pit scales (Sternorrhyncha: Coccoidea) of North and South America. Tennessee Agricultural Experiment Station, University of Tennessee, Institute of Agriculture Knoxville, Tennessee, 231 pp.

Sugonyaev ES (1965) Palearctic species of the genus Blastothrix Mayr (Hymenoptera, Chalcidoidea) with remarks on their biology and useful role. Part 2. Entomological Review 44: 225-233.

Szulczewski JW (1921) A contribution to fauna Coccidae of Wielkopolska. Prace Komisji Fizjograficznej, Poznań 1: 78-84. [In Polish]

Szulczewski JW (1926) Data for the scale insect fauna of Poznań. Polskie Pismo Entomologiczne 5: 137-143. [In Polish]

Trzebiński J (1916) Diseases and pests of plants in the Kingdom of Poland. According to data from the Plant Protection Station from 1912, 1913 and 1914 with earlier data attached. Pamiętnik Fizjograficzny 23(3): 1-106. [In Polish]

Wünn H (1919) Über die Cocciden des Urwaldes von Bialovies. Abh. Senckenb. Naturforsch. Ges. 37: 1-21.

Żak-Ogaza B (1961) Research on chalcid wasps (Hymenoptera, Chalcidoidea) parasitoids of scale insects (Homoptera, Coccoidea) from Poland. Polskie Pismo Entomologiczne 31: 349-410. [In Polish]

Żak-Ogaza B, Koteja J (1964) Investigations on scale insects (Homoptera, Coccoidea) of the Pieniny Mountains. Acta Zoologica Cracoviensia 9: 417-439. 